\title{
MANAJEMEN LABA: BAGAIMANA DAMPAKNYA TERHADAP IPO UNDERPRICING?
}

\author{
Andre Yulius Sahat Nauli Sitompul, Unggul Purwohedi, Ari Warokka \\ Program Studi Magister Manajemen Universitas Negeri Jakarta \\ Gedung RA Kartini Lt.9 Kampus A, Jl. Rawamangun Muka, Jakarta, 13220, Indonesia
}

\begin{abstract}
Keywords: abnormal cash flow, abnormal production cost, abnormal discretionary expenses, discretionary accruals, IPO Underpricing

JEL Classification: G23, G32

The purpose of this research was to investigate the effect of accrual and real earning management on IPO underpricing which was measured by initial return, on the first day of trading in Indonesia Stock Exchange, of Indonesian manufacturing companies during 2010-2014. This research was conducted using purposive sampling technique from 20 analyzed manufacturing companies. Earnings management variable was measured using discretionary accruals, abnormal cash flow, abnormal production cost, and abnormal discretionary expenses while IPO underpricing was calculated using the initial return on the first day of stock trading in stock exchange. This research used ordinary least squares technique (OLS) multiple linear regression analysis. The result of this study revealed that the real earning management practice through abnormal cash flow had a positive effect on IPO underpricing while the other earnings management proxy had a negative significant effect on underpricing. This finding indicated that every earnings management practice could give an effect in a different direction on IPO underpricing phenomenon, as a response of investors on the published company's performance. Hence, this study's finding provided a significant empirical contribution to the signalling theory, in particularly for the issue of IPO underpricing in Indonesian Capital Market practices.
\end{abstract}

Kata kunci: arus kas abnormal, diskresioner akrual, biaya diskresioner abnormal, biaya produksi abnormal, IPO Underpricing

\section{ABSTRAK}

Penelitian ini bertujuan untuk melihat pengaruh manajemen laba akrual dan riil terhadap IPO underpricing yang diukur dengan initial return hari pertama perdagangan saham di bursa pada perusahaan-perusahaan manufaktur yang melakukan IPO di Bursa Efek Indonesia periode Tahun 2010-2014. Penelitian ini menggunakan teknik purposive sampling dengan total 20 perusahaan manufaktur yang dianalisis. Variabel manajemen laba diukur dengan menggunakan proksi discretionary accruals, abnormal cash flow, abnormal production cost, dan abnormal discretionary expenses. Sedangkan, variabel underpricing dihitung menggunakan initial return pada hari pertama perdagangan saham di bursa. Penelitian ini menggunakan teknik ordinary least squares (OLS) multiple linear regression analysis. Hasil dari penelitian ini menemukan bahwa praktik manajemen laba riil melalui abnormal cash flow berpengaruh positif signifikan terhadap adanya fenomena underpricing. Sementara, proksi manajemen laba lainnya berpengaruh negatif signifikan terhadap underpricing. Hal ini tentunya mengindikasikan bahwa setiap praktik manajemen laba dapat memberikan pengaruh dalam arah yang berbeda terhadap fenomena IPO underpricing, sebagai respons investor atas kinerja perusahaan yang dipublikasikan. Hal ini tentunya memberikan kontribusi empiris bagi teori sinyal pada praktek Pasar Modal Indonesia, khususnya dalam topik IPO underpricing. 


\section{Manajemen Laba: Bagaimana Dampaknya terhadap Ipo Underpricing?}

Andre Yulius Sahat Nauli Sitompul, Unggul Purwohedi, \& Ari Warokka

Anomali yang terjadi pada penawaran saham perdana (Initial Public Offering/IPO) ke publik menunjukkan adanya kecenderungan bahwa saham akan mengalami underpriced pada saat saham tersebut go public di lantai bursa. Underpricing secara umum digambarkan sebagai kondisi di pasar sekunder di mana harga saham yang ditawarkan di pasar perdana (IPO) lebih rendah dibandingkan harga penutupan di pasar sekunder yang menyebabkan adanya return yang positif pada hari pertama perdagangan di bursa (Beatty \& Ritter, 1986; Fung et al., 2014; Katti \& Phani, 2016).

Bagi investor, saham yang underpriced akan memberikan intial return yang positif setelah saham tersebut diperdagangkan di bursa. Munculnya respon positif dari pasar tersebut akibat kinerja perusahaan yang terlihat "baik" menjadi salah satu tujuan dilakukannya manajemen laba. Namun, upaya manipulasi ini tidak dapat dilakukan terusmenerus dalam jangka panjang, hal ini dikarenakan akan berdampak pada penurunan kinerja saham perusahaan. Telah banyak penelitian yang menjelaskan fenomena underpricing dengan praktek manajemen laba khususnya manajemen laba akrual yang terjadi selama periode IPO (Shen et al., 2014; Karami et al., 2014; Gao et al., 2015; Alhadab et al., 2016). Shen, et.al. (2014) menemukan bahwa praktek manajemen laba melalui discretionary accruals memiliki hubungan yang positif dengan fenomena underpricing, sebagaimana yang dikemukakan pula oleh Beatty \& Ritter (1986) bahwa underpricing memiliki hubungan yang positif dengan ketidakpastian (uncertainty) atas harga saham pada saat IPO. Namun di sisi lain, beberapa penelitian terdahulu menunjukkan masih adanya perbedaan hasil tentang bagaimana sesungguhnya manajemen laba berpengaruh terhadap fenomena underpricing. Penelitian yang dilakukan oleh Gao et al. (2015) menemukan adanya perbedaan arah pengaruh manajemen laba terhadap underpricing saham. Mereka menemukan bahwa komponen current discretionary accruals memiliki pengaruh ne- gatif terhadap underpricing, sedangkan total dan long term discretioanry accruals memiliki arah hubungan sebaliknya. Menurut Kao et al. (2009) yang menemukan bahwa manajemen laba yang agresif akan menurunkan tingkat return saham-saham di hari pertama perdagangan di bursa, sedangkan, menurut penelitian Karami et al. (2014) menemukan bahwa praktek manipulasi laba (earning manipulation) tidak berpengaruh secara signifikan terhadap kecenderungan underpricing saham-saham yang go public. Berdasarkan research gap tersebut, ditambah adanya keterbatasan penelitian yang meneliti pengaruh manajemen laba riil terhadap IPO underpricing (Alhadab et al., 2016), maka penelitian ini akan meneliti kembali bagaimana pengaruh manajemen laba akrual dan riil terhadap IPO underpricing di Indonesia.

Penelitian ini bertujuan menganalisis pengaruh manajemen laba yang dilakukan oleh manajemen perusahaan satu tahun sebelum IPO terhadap adanya underpricing pada hari pertama di bursa pada sektor manufaktur di Bursa Efek Indonesia yang melakukan IPO di Indonesia dalam periode 20102014. Sektor manufaktur menjadi pilihan mengingat kontribusi sektor tersebut bagi pertumbuhan ekonomi dan kinerja ekspor nasional dibandingkan sektor lainnya.

\section{PENGEMBANGAN HIPOTESIS}

Secara umum, fenomena IPO underpricing dapat dijelaskan melalui dua perspektif teori: (1) Agency theory dan (2) Signalling theory. Perspektif agency theory, IPO underpricing terjadi karena investor berasumsi adanya kondisi asymmetric information antara principal (investor) dan agent (eksekutif perusahaan). Asymmetric information ini terkait tentang kinerja perusahaan sesungguhnya pada saat perusahaan melakukan IPO, yang kemudian menyebabkan investor akan lebih berhati-hati (tidak ingin terlalu berisiko) dalam menentukan besaran harga yang akan dibayarkan pada saat IPO. 


\section{Jurnal Keuangan dan Perbankan | KEUANGAN}

Vol. 21, No. 2, April 2017: 228-237

Kondisi ini kemudian akan berdampak pada lebih rendahnya harga yang ditawarkan di pasar perdana dibandingkan harga perdagangan pada hari pertama di lantai bursa (Beatty \& Ritter, 1986; Alhadab et al., 2016; Katti \& Phani, 2016).

Dalam perspektif signalling theory, IPO underpricing dapat dipahami ketika perusahaan perlu untuk mengirimkan sejumlah sinyal kepada investor bahwa mereka adalah perusahaan yang baik dan berkualitas. Berdasarkan teori ini, perusahaan yang 'baik' akan menghasilkan return yang 'baik' pula (Katti \& Phani, 2016). Oleh sebab itu, perusahaan akan mencoba untuk menjadi baik dengan berbagai cara, salah satunya melalui praktek manajemen laba (Gao et al., 2015). Dengan melakukan praktek manajamen laba, maka perusahaan akan dipersepsikan sebagai perusahaan yang berkualitas yang kemudian akan terefleksi dengan adanya return positif pada saat perdagangan saham di pasar sekunder. Perusahaan yang melakukan manajemen laba bertujuan untuk meningkatkan nilai perusahaan pada saat IPO, sehingga diharapkan akan memperoleh return yang positif pada hari pertama di bursa. Penelitian DuCharme et al. (2001) menyatakan bahwa manajemen laba sebelum IPO memengaruhi initial return perusahaan secara positif. Konsep signalling inilah yang kemudian dijadikan landasan teori bagi peneliti dalam memahami keterkaitan antara manajemen laba dan IPO underpricing, dengan mengajukan beberapa hipotesis yang akan dijelaskan dalam sub-bab berikutnya.

\section{Pengaruh Manajemen Laba Akrual terhadap IPO Underpricing}

Peneliti terdahulu telah menemukan bukti empiris yang menguatkan bahwa perusahaan cenderung melakukan tindakan akrual atas labanya agar terlihat lebih baik (atau dikenal dengan positive accruals) selama periode IPO (Aharony et al., 1993; Teoh et al., 1998a; Teoh et al., 1998b; Aharony et al., 2000; Ducharme et al., 2001; Roosenboom, Goot, \& Mertens, 2003; Yu et al., 2006). Praktek manajemen laba ini dimotivasi oleh adanya keinginan untuk dapat memengaruhi harga penawaran maupun tingkat return saham di kemudian hari (Shen et al., 2014). Secara empiris, Shen et al. (2009) dan Shen et al. (2014) menemukan bahwa manajemen laba melalui diskresi akrual sebelum IPO berpengaruh positif terhadap underpricing pada hari pertama bursa. Berdasarkan kajian empiris tersebut, penelitian ini mengajukan hipotesis pertama sebagai berikut:

$\mathrm{H}_{1}$ : praktek manajemen laba akrual melalui komponen diskresi akrual (DACit) satu tahun sebelum IPO berpengaruh positif terhadap underpricing saham pada hari pertama bursa.

\section{Pengaruh Manajemen Laba Riil terhadap IPO Underpricing}

Beberapa penelitian terdahulu telah menemukan bahwa selain melakukan manajemen laba akrual, perusahaan yang sedang IPO juga memiliki kecenderungan untuk melakukan manajemen laba riil. Berbeda dengan manajemen laba akrual yang menitikberatkan pada metode akuntansi yang digunakan, manajemen laba riil mengandalkan perubahan pada aspek waktu dan struktur transaksi dalam kelompok operasi, investasi, maupun pendanaan (Li, 2010). Penelitian yang dilakukan oleh Darrough \& Rangan (2005) menemukan bahwa manajer akan cenderung untuk menurunkan biaya penelitian dan pengembangan ( $R \mathcal{E} D$ expenses) untuk meningkatkan laba tahun berjalan. Mereka meyakini bahwa investor akan menaruh perhatian yag besar pada laba yang dilaporkan. Graham et al. (2005) menemukan bukti empiris bahwa eksekutif perusahaan memiliki kecenderungan untuk melakukan manajemen laba rill dibandingkan akrual. Mereka berargumen bahwa manipulasi melalui manajemen laba rill lebih sulit dideteksi oleh auditor, pemerintah, dan investor dibandingkan 


\section{Manajemen Laba: Bagaimana Dampaknya terhadap Ipo Underpricing?}

Andre Yulius Sahat Nauli Sitompul, Unggul Purwohedi, ঔ Ari Warokka

akrual. Alhadab et al. (2016) menemukan bahwa perusahaan-perusahaan yang melakukan IPO di Bursa Saham Inggris telah melakukan praktek manajemen laba rill berupa discretionary expenses manipulation khususnya dengan mengurangi biaya diskresioner seperti R\&D, dan juga praktek abnormal cash flow, khususnya dengan meningkatkan kinerja penjualan secara pelaporan. Kesimpulan yang sama juga dikemukakan oleh Li (2010) yang menemukan bahwa adanya hubungan yang erat antara Real Earnings Management (REM) dengan return perusahaan, menemukan bahwa abnormal operating cash flow yang rendah (tinggi) akan menyebabkan underperform (outperform) return saham di periode berikutnya. Abnormal operating cash flow yang dimaksud bersumber dari pengeluaran (expenses) dalam kegiatan operasi perusahaan. Dimana, perusahaan yang cenderung menahan pengeluaran cash flownya untuk memperoleh profil pendapatan yang baik, cenderung akan berpengaruh linier dengan return sahamnya akan menurun di tahun mendatang (Roychowdhury, 2006; Li, 2010). Selanjutnya, perusahaan yang memiliki abnormal production cost yang rendah (tinggi) akan berdampak pada outperform (underperform) return saham pada periode berikutnya. Berdasarkan penelitianpenelitian di atas, penelitian ini mengajukan hipotesis kedua sebagai berikut:

$\mathrm{H}_{2}$ : praktek manajemen laba riil melalui abnormal cash flow satu tahun sebelum IPO berpengaruh positif terhadap underpricing $\left(\mathrm{H}_{2 \mathrm{a}}\right)$, sedangkan komponen biaya produksi abnormal $\left(\mathrm{H}_{2 \mathrm{~b}}\right)$ dan biaya diskresioner abnormal $\left(\mathrm{H}_{2 \mathrm{c}}\right)$ satu tahun sebelum IPO berpengaruh negatif terhadap underpricing, pada hari pertama bursa.

\section{METODE}

Penelitian ini menggunakan metode purposive sampling, dengan ketentuan sebagai berikut: (1) Perusahaan yang diteliti adalah industri manufaktur yang melakukan IPO di Bursa Efek Indo- nesia (BEI) tahun 2010-2014; (2) Perusahaan memiliki laporan keuangan satu tahun sebelum IPO; (3) Data-data mengenai komponen akrual dan riil tersedia lengkap dalam laporan keuangan perusahaan; (4) Data mengenai historis harga saham dan indeks pasar masing-masing bursa tersedia lengkap. Sepanjang Tahun 2010-2014 terdapat 125 perusahaan yang melakukan IPO dimana 20 diantaranya adalah perusahaan manufaktur.

\section{Operasionalisasi Variabel Penelitian}

Penelitian ini, model yang digunakan untuk menghitung DAC (Discretionary Accrual) menggunakan Modified Jones Models yang dilakukan oleh Dechow et al. (1995). Sedangkan untuk menghitung manajemen laba rill, baik abnormal cash flow, abnormal production cost, dan abnormal discretionary expenses, penelitian ini mengadpsi proksi yang digunakan oleh Roychowdhury (2006). Kemudian, peneliti menggunakan proksi initial return untuk menghitung underpricing sebagaimana yang telah digunakan oleh Fung et al. (2014). Operasionalisasi masing-masing variabel dapat dilihat pada Tabel 1.

Teknik analisis yang digunakan dalam penelitian ini adalah multiple linier regression analysis yang menggambarkan hubungan secara linear antara dua atau lebih variabel independen dengan variabel dependen. Teknik ini digunkan untuk mengetahui arah hubungan antara variabel independen dengan variabel dependen apakah masingmasing variabel independen berhubungan positif atau negatif, dan untuk memprediksi nilai dari variabel dependen apabila nilai variabel independen mengalami kenaikan atau penurunan. Peneliti menggunakan software Eviews untuk menghasilkan persaman regresi dengan pendekatan common OLS Model yang mengasumsikan model konstan terhadap waktu karena penelitian ini hanya mengcapture saat perusahaan IPO dan diperdagangkan di lantai bursa. 


\section{Jurnal Keuangan dan Perbankan | KEUANGAN}

Vol. 21, No. 2, April 2017: 228-237

Tabel 1. Operasionalisasi dan Pengukuran Variabel

\begin{tabular}{|c|c|c|}
\hline Variabel & Proksi & Pengukuran \\
\hline \multicolumn{3}{|l|}{ Variabel dependen } \\
\hline IPO Underpricing & Initial Return (IRit) & $\left(\right.$ IRit $\left.=\frac{\text { Pit }}{\text { Pio }}-1\right) \times 100 \%$ \\
\hline \multicolumn{3}{|l|}{ Variabel Independen } \\
\hline Manajemen Laba Akrual & $\begin{array}{l}\text { Discretionary Accruals } \\
\text { (DACit) }\end{array}$ & 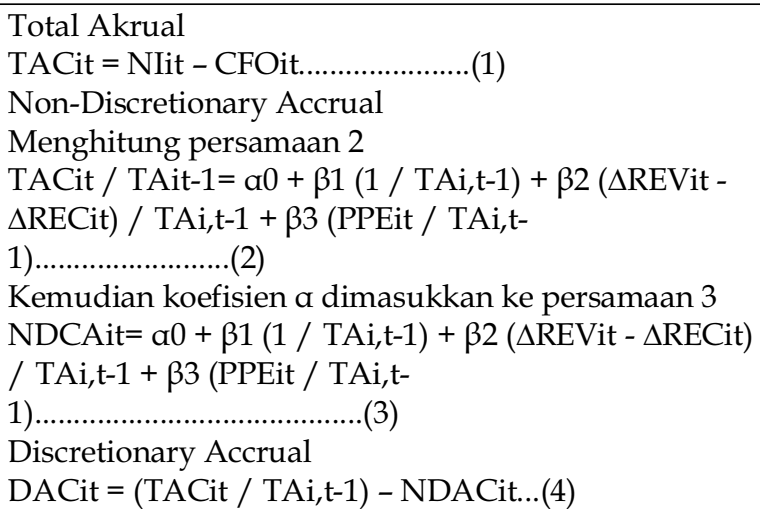 \\
\hline $\begin{array}{l}\text { Manajemen Laba Riil arus } \\
\text { Kas Operasi }\end{array}$ & $\begin{array}{l}\text { Abnormal Cash Flow } \\
\left(\mathrm{AB} \_\mathrm{CFO}\right)\end{array}$ & $\begin{array}{l}\text { CFOit / Ait-1 = a0 + } \beta 1(1 / \text { Ait-1) }+\beta 2 \text { (SALESit / } \\
\text { Ait-1) }+\beta 3(\triangle S A L E S i t ~ / ~ A i t-1)+ \\
\text { cit....................................... } 5) \\
\text { Kemudian dimasukkan ke: } \\
\text { AB_CFO = CFOit - CFOit / Ait-1.......(6) }\end{array}$ \\
\hline $\begin{array}{l}\text { Manajemen Laba Riil Biaya } \\
\text { produksi }\end{array}$ & $\begin{array}{l}\text { Abnormal Production Cost } \\
\text { (AB_PROD) }\end{array}$ & $\begin{array}{l}\text { PRODit= COGSit + } \Delta \text { INVit.................(7) } \\
\text { Dimana, } \\
\text { PRODit / Ait-1 = a0 + } \beta 1(1 / \text { Ait-1) + } \beta 2 \text { (SALESit / } \\
\text { Ait-1) + } \beta 3(\triangle \text { SALESit / Ait-1) + } \\
\text { cit....................................(8) } \\
\text { Kemudian dimasukkan ke: } \\
\text { AB_PROD = PRODit - PRODit / Ait-1....(9) }\end{array}$ \\
\hline $\begin{array}{l}\text { Manajemen Laba Riil Biaya } \\
\text { Diskresioner }\end{array}$ & $\begin{array}{l}\text { Abnormal Discretionary } \\
\text { Expenses (AB_DISC) }\end{array}$ & $\begin{array}{l}\text { DISCit / Ait-1 = a0 + } \beta 1(1 / \text { Ait-1) }+\beta 2 \text { (SALESit-1 / } \\
\text { Ait-1) + cit.................(10) } \\
\text { Kemudian dimasukkan ke: } \\
\text { AB_DISC = DISCit - DISCit / Ait-1........(11) }\end{array}$ \\
\hline
\end{tabular}

\section{Keterangan:}

Initial Return

IRit = initial return perusahaan $\mathrm{i}$ pada hari pertama $\mathrm{t}$

Pit = harga penutupan (closing price) perusahaan i pada hari pertama $\mathrm{t}$

Pio = harga penawaran (offering price) perusahaan $\mathrm{i}$ pada hari pertama $\mathrm{t}$

Persamaan...... (1)

TACit = total accruals perusahaan $\mathrm{i}$ pada periode $\mathrm{t}$

Nlit = laba bersih operasi (Net Operating Income) perusahaan i pada periode $\mathrm{t}$

CFO it = cash flow from operating perusahaan $\mathrm{i}$ pada periode $\mathrm{t}$

Persamaan........... (2) dan (3)

NDACCit $=$ Non Discretionary Accruals perusahaan $\mathrm{i}$ pada periode $\mathrm{t}$

$\mathrm{TAi}, \mathrm{t}-1=$ total aktiva perusahaan $\mathrm{i}$ pada periode $\mathrm{t}-1$

$\triangle$ REVit = pendapatan perusahaan i pada tahun $\mathrm{t}$ dikurangi pendapatan $\mathrm{t}-1$

$\triangle$ RECit = piutang dagang perusahaan $\mathrm{i}$ pd tahun $\mathrm{t}$ dikurangi piutang dagang tahun $\mathrm{t}-1$

Persamaan.......... (4)

DACit = discretionary accruals perusahaan $\mathrm{i}$ pada periode $\mathrm{t}$

TACit = total accruals perusahaan $\mathrm{i}$ pada periode $\mathrm{t}$

$\mathrm{TAi}, \mathrm{t}-1=$ total aktiva perusahaan $\mathrm{i}$ pada periode $\mathrm{t}-1$

NDACit = Non Discretionary Accruals perusahaan $\mathrm{i}$ pada periode $\mathrm{t}$ 


\section{Manajemen Laba: Bagaimana Dampaknya terhadap Ipo Underpricing?}

Andre Yulius Sahat Nauli Sitompul, Unggul Purwohedi, \& Ari Warokka

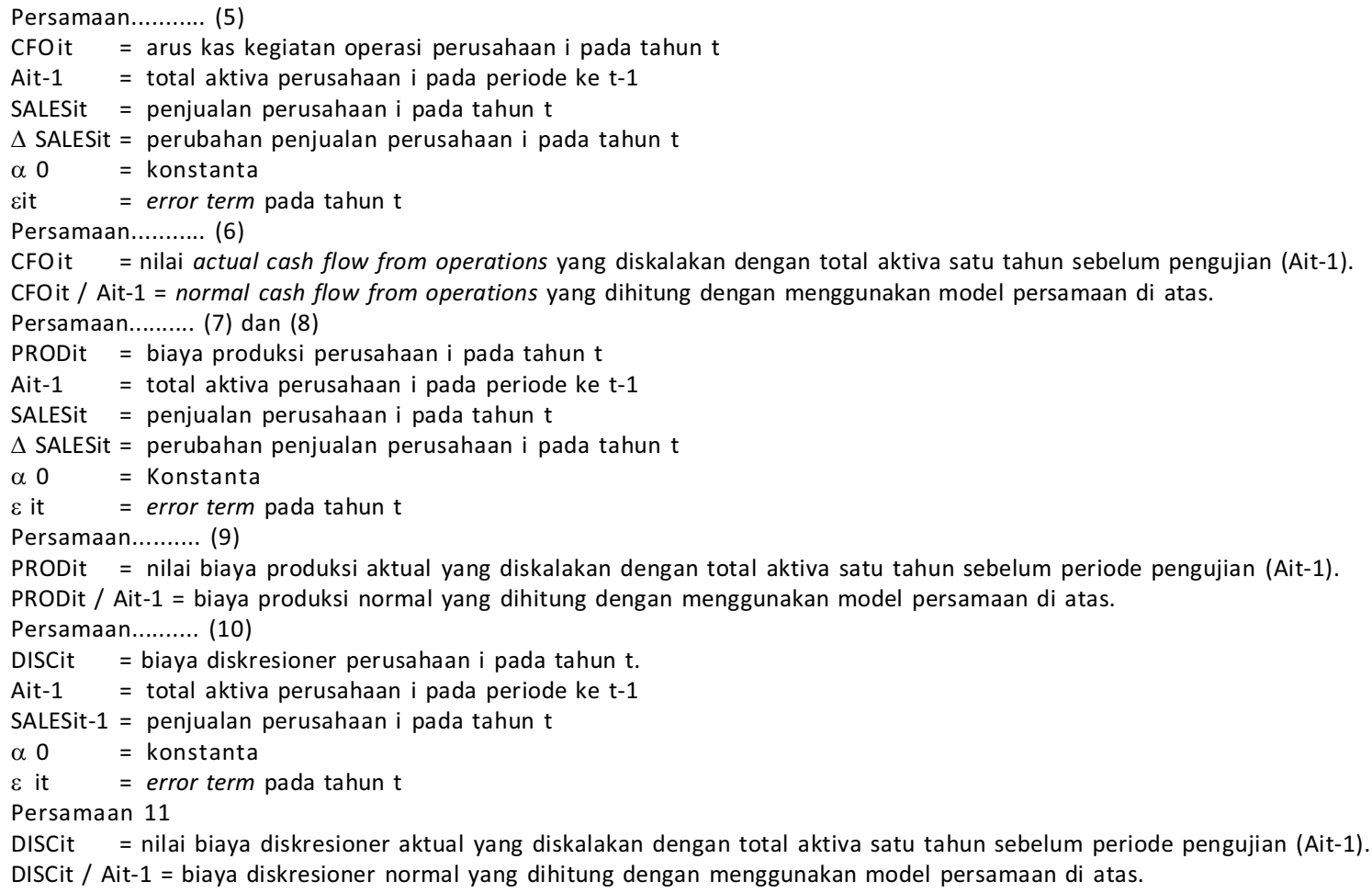

Penelitian ini menggunakan suatu model underpricing yang bertujuan untuk menguji pengaruh manajemen laba akrual dan riil satu tahun sebelum IPO terhadap underpricing hari pertama di bursa sebagai berikut:

$$
\begin{aligned}
\text { IRit }= & \alpha 0+\beta 1 D A C i, t-1+\beta 2 \text { AB_CFOi,t }-1+ \\
& \beta 3 \text { AB_PRODi,t }-1+\beta 4 \text { AB_DISCi,t }-1+\varepsilon i
\end{aligned}
$$

\section{Dimana:}

IRit

DACi,t-1

= return hari pertama

= total akrual diskresioner 1 tahun sebelum IPO

AB_CFOi,t-1 = abnormal $\mathrm{CFO} 1$ tahun sebelum IPO

AB_PRODi,t-1 = abnormal biaya produksi 1 tahun sebelum IPO

AB_DISCi,t-1 = abnormal biaya diskresi 1 tahun sebelum IPO
$=$ error
HASIL

\section{Uji Asumsi Klasik}

Untuk normalitas, penelitian ini menggunakan uji Jarque-Bera dimana model regresi menunjukkan nilai Jarque-Bera sebesar 1,992 dan probabilitas 0,369 . Oleh karena itu data berdistribusi normal karena nilai signifikan probabilty JarqueBera lebih besar dari 0,05 (Ghozali \& Ratmono, 2014).

Hasil pengujian Multikolinearitas menggunakan Variance Inflation Factor (VIF), dimana tidak terdapat variabel yang menghasilkan nilai VIF yang lebih besar dari 10. Dimana, nilai VIF untuk DACit, AB_CFO, AB_PROD, AB_DISC, masingmasing sebesar 1.285698, 1.465109, 1.358915, 1.220438. Sehingga dapat disimpulkan tidak terdapat, multikoliniearitas dalam persamaan regresi (Ghozali \& Ratmono, 2014). 


\section{Jurnal Keuangan dan Perbankan | KEUANGAN}

Vol. 21, No. 2, April 2017: 228-237

Penelitian ini menggunakan metode Glejser untuk melihat adanya heteroskedastisitas, dimana model regresinya menunjukkan nilai probabilitas uji F yang tidak signifikan 0,1650 (lebih besar dari 0,05 ) yang mengindikasikan bahwa masing-masing variabel independen tidak memiliki pengaruh yang signifikan untuk memprediksi variabel independen. Sehingga, model Glejser tidak mengindikasikan adanya masalah heteroskedastisitas (Ghozali \& Ratmono, 2014).

Pengujian autokorelasi dilakukan dengan menggunakan nilai Durbin-Watson (DW) dengan uji Lagrange Multiplier (LM Test), dan ditemukan bahwa nilai dw model regresi sebesar 2,0386 dimana nilai du sebesar 1,823 dan 4-du sebesar 2,177. Sehingga nilai $\mathrm{dw}$ terletak pada area $\mathrm{du}<\mathrm{dw}<4$ du sehingga dapat dikatakan tidak terjadi masalah autokorelasi (Ghozali \& Ratmono, 2014).

\section{Hasil Regresi dan Pengujian Hipotesis}

Menggunakan metode regresi berganda common OLS model dengan software EViews, maka diperoleh hasil sebagai berikut:

Tabel 2 menunjukkan nilai signifikansi variabel diskresi akrual (DACit) lebih kecil dari 0,05, namun praktek manajemen laba akrual melalui komponen diskresi akrual (DAC) satu tahun sebelum IPO berpengaruh negatif terhadap initial return pada hari pertama di bursa yang bertolak belakang dengan arah yang dihipotesiskan. Oleh sebab itu, hasil ini menunjukkan bahwa $\mathrm{H}_{1}$ tidak diterima. Tabel 2 menunjukkan bahwa variabel abnormal cash flow (AB_CFO) menunjukkan angka signifikansi probabilitas di bawah 0,05 yang berarti variabel abnormal cash flow memiliki hubungan yang positif dan signifikan terhadap initial return pada hari pertama di bursa. Dengan kata lain, hipotesis $\mathrm{H}_{2 \mathrm{a}}$ diterima. Tabel 2 juga menunjukkan bahwa nilai signifikansi variabel biaya produksi abnormal ( $\mathrm{AB}_{-}$ PROD) lebih kecil dari 0,05 yang artinya praktek manajemen laba riil melalui komponen biaya produksi abnormal (AB_PROD) satu tahun sebelum IPO berpengaruh negatif signifikan terhadap initial return pada hari pertama di bursa. Hal ini menunjukkan bahwa hipotesis $\mathrm{H}_{2 \mathrm{~b}}$ diterima. Berikutnya, hasil uji t pada Tabel 2 menunjukkan nilai signifikansi variabel biaya diskresioner abnormal ( $\mathrm{AB}_{-}$ DISC) lebih kecil dari 0,05 yang artinya praktek manajemen laba riil melalui komponen biaya diskresioner abnormal (AB_DISC) satu tahun sebelum IPO berpengaruh negatif signifikan terhadap underpricing pada hari pertamadi bursa. Hal ini menujukan hipotesis $\mathrm{H}_{2 \mathrm{c}}$ diterima. Hasil penelitian da-

Tabel 2. Hasil Regresi Manajemen Laba terhadap Underpricing

\begin{tabular}{|c|c|c|c|c|}
\hline Variable & Coefficient & Std. Error & t-Statistic & Prob. \\
\hline Discretionary Accrual & $-0,521356$ & 0,137441 & $-3,793306$ & 0,0018 \\
\hline Abnormal Production Cost & $-0,376242$ & 0,110938 & $-3,391470$ & 0,0040 \\
\hline Abnormal Discretionary Exp. & $-0,485083$ & 0,140492 & $-3,452749$ & 0,0036 \\
\hline Abnormal Cash Flow & 0,355246 & 0,149637 & 2,374048 & 0,0314 \\
\hline Constant & 0,245217 & 0,033290 & 7,365973 & 0,0000 \\
\hline R-squared & 0,626991 & Mean dependent var & & 0,172950 \\
\hline Adjusted R-squared & 0,527522 & S.D. dependent var & & 0,147760 \\
\hline S.E. of regression & 0,101566 & Akaike info criterion & & $-1,523901$ \\
\hline Sum squared resid & 0,154734 & Schwarz criterion & & $-1,274968$ \\
\hline Log likelihood & 20,23901 & Hannan-Quinn criter. & & $-1,475307$ \\
\hline F-statistic & 6,303370 & Durbin-Watson stat & & 2,377559 \\
\hline Prob(F-statistic) & 0,003499 & & & \\
\hline
\end{tabular}




\section{Manajemen Laba: Bagaimana Dampaknya terhadap Ipo Underpricing?}

Andre Yulius Sahat Nauli Sitompul, Unggul Purwohedi, \& Ari Warokka

pat dikatakan bahwa seluruh proksi manajemen laba akrual terbukti secara empiris memiliki arah pengaruh sesuai yang dihipotesiskan, sedangkan manajemen laba akrual memiliki arah yang bertolak belakang dengan yang dihipotesiskan.

\section{PEMBAHASAN}

Penelitian ini menemukan bahwa perusahaan manajemen laba riil yang dilakukan perusahaan telah berpengaruh kepada initial return saham pada hari pertama perdagangan. Hal ini sesuai dengan teori signalling yang menjadi landasan penelitian ini, bahwa perusahaan akan melakukan upaya semaksimal mungkin untuk memberikan kesan perusahaan yang 'baik' atau 'berkualitas' kepada investor sehingga hal tersebut akan terefleksi pada fenomena adanya return yang positif pada hari pertama di bursa (Katti \& Phani, 2016). Secara spesifik, penelitian ini menemukan bahwa praktikpraktik manajemen laba rill melalui pengelolaan cash flow, biaya produksi dan biaya diskresioner mampu secara efektif meningkatkan return perusahaan pada hari pertama di pasar sekunder. Hal ini sejalan dengan penelitian-penelitian terdahulu, seperti Alhadab et al. (2016) yang menemukan bahwa perusahaan-perusahaan di Inggris telah melakukan manajemen laba riil secara intens khususnya dengan melakukan praktik abnormal cash flow dan abnormal discretionary expenses. Secara tidak langsung, penelitian ini mengindikasikan bahwa perusahaan-perusahaan yang menjadi sampel telah mengandalkan praktik-praktik manajemen laba rill untuk memberikan kesan yang 'baik' atas perusahaan mereka. Hasil uji hipotesis $\mathrm{H} 2 \mathrm{a}, \mathrm{H} 2 \mathrm{~b}$ dan $\mathrm{H} 2 \mathrm{c}$ juga sejalan dengan penelitian terdahulu yang dilakukan Oktorina \& Hutagaol (2008), Roychowdhury (2006), dan Li (2010). Menurut Oktorina \& Hutagaol (2008) perusahaan yang melakukan manipulasi riil melalui arus kas operasi memiliki kinerja pasar yang lebih tinggi daripada perusahaan yang tidak melakukan manipulasi aktivitas riil melalui arus kas kegiatan operasi. Hasil inipun sejalan de- ngan Li (2010) yang membuktikan bahwa manajemen laba riil melalui manipulasi arus kas berpengaruh positif terhadap initial return. Hasil ini dapat disebabkan karena manajemen laba riil melalui arus kas kegiatan operasi merupakan bentuk tindakan manajemen dalam akuntansi kreatif untuk mencapai target laba yang diinginkan. Manipulasi riil melalui arus kas operasi membuat laba tahun berjalan meningkat sehingga permintaan saham juga tinggi pada saat IPO. Permintaan saham yang tinggi membuat perusahaan memperoleh return positif pada hari pertama bursa.

Penelitian ini menemukan hasil yang berbeda dengan penelitian terdahulu tentang pengaruh manajemen laba akrual terhadap IPO underpricing. Penelitian ini menemukan bahwa discretionary accrual berpengaruh negatif terhadap initial return, dimana penelitian sebelumnya banyak menemukan pengaruh yang positif (Shen et al, 2009; DuCharme et al.,2001). Perspektif signalling theory, arah pengaruh ini dapat dimaknai sebagai kurang efektifnya praktik manajemen laba akrual dalam memberikan kesan yang 'baik' bagi para investor. Di sisi lain, hasil penelitian ini seolah menegaskan bahwa investor akan bersikap lebih skeptis atas tindakan manajemen laba yang agresif. Hasil penelitian ini sejalan dengan Kao et al. (2009) yang menemukan bahwa manajemen laba yang agresif (aggressive earnings management) sebelum IPO cenderung untuk menurunkan tingkat keuntungan begitupun kinerja saham setelah IPO di bursa. Hal ini terjadi karena manajemen laba tidak akan mampu menghasilkan hasil yang stabil dalam jangwa waktu lama. Hasil penelitian sejalan dengan temuan Gao et al. (2015) yang menunjukkan bahwa beberapa komponen manajemen laba memiliki hubungan yang tidak signifikan bahkan negatif terhadap underpricing. Hal ini terjadi karena investor tidak dapat secara cepat merespons informasi laba yang ditampilkan oleh perusahaan dalam waktu singkat, sehingga harga (return) saham tidak otomatis naik setelah dilakukannya IPO dikarenakan pemahaman yang beragam dari investor dalam memahami laporan keuangan. 


\section{Jurnal Keuangan dan Perbankan | KEUANGAN}

Vol. 21, No. 2, April 2017: 228- 237

\section{SIMPULAN DAN SARAN}

\section{Simpulan}

Penelitian ini bertujuan untuk mengetahui bagaimana sesungguhnya pengaruh manajemen laba terhadap fenomena IPO underpricing yang ada di Indonesia. Penelitian ini menggunakan 20 sampel perusahaan manufaktur yang melakukan IPO dalam kurun waktu Tahun 2010-2014. Penelitian ini membagi manajemen laba ke dalam dua klasifikasi yaitu manajemen laba akrual dan manajemen laba rill, dimana manajemen laba akrual diproksikan dengan discretionary accrual yang merupakan total akrual dari pendapatan dan piutang yang dimiliki perusahaan 1 tahun sebelum IPO, sedangkan manajemen laba rill berfokus kepada tiga proksi yaitu: abnormal cash flow, abnormal production cost, dan abnormal discretionary expenses satu tahun sebelum IPO. Di sisi lain, underpricing diukur dengan menggunakan initial return saham pada hari pertama perdagangan di lantai bursa. Penelitian ini menemukan bukti yang empiris bahwa praktek manajemen laba akrual berpengaruh negatif terhadap initial return bertolak belakang dengan hipotesis. Di sisi lain, manajemen laba riil memiliki arah pengaruh sesuai dengan hipotesis dimana abnormal cash flow memiliki hubungan yang positif dengan IPO underpricing, sedangkan abnormal production cost dan abnormal discretionary expenses memiliki hubungan yang negatif dengan IPO underpricing. Hasil penelitian ini tidak hanya berkontribusi dengan memberikan bukti empiris baru tentang adanya pengaruh yang signifikan praktek manajemen rill terhadap initial return ditengah keterbatasan penelitian yang ada, namun juga menjelaskan bagaimana sesungguhnya perusahaan melakukan proses signalling dalam perspektif signalling theory.

\section{Saran}

Hasil penelitian ini diharapkan dapat bermanfaat bagi dunia praktek, pengembangan ilmu, dan penelitian selanjutnya. Bagi perusahaan, hasil penelitian ini menunjukkan bahwa praktek manajemen laba yang sangat agresif seperti melalui praktek discretionary accrual justru akan berdampak kontraproduktif terhdapa return yang dihasilkan, dan tentunya citra perusahaan. Hasil penelitian ini yang menemukan bahwa manajemen laba rill lebih efektif dalam memengaruhi return, juga menyiratkan bahwa perusahaan diharapkan lebih membenahi kinerja internal mereka khususnya pada aktivitas operasional dan efisiensi agar mereka dapat benar-benar menjadi perusahaan yang baik di mata investor.

Bagi literatur, penelitian ini memberikan kontribusi bukti emprisi baru tentang bagaimana sesungguhnya perusahaan melakukan proses 'signalling' kepada investor dalam paradigma signalling theory. Diperlukan bukti-bukti empiris baru tentang bagaimana mekanisme sesungguhnya perusahaan melakukan praktik manajemen laba khususnya di sekitar pelaksanaan IPO.

Bagi penelitian selanjutnya, perlu dilakukan kajian yang lebih mendalam tentang model perhitungan manajemen laba Indonesia khususnya manajemen laba riil, ini dikarenakan beragamnya model pilihan perhitungan manajemen laba yang ada. Diharapkan pula, penelitian selanjutnya juga dapat meneliti saham-saham selain sektor manufaktur sehingga diperoleh perspektif yang lebih luas tentang pengaruh manajemen laba terhadap underpricing dalam sektor industri yang berbeda. Penelitian tentang dampak manajemen laba terhadap return perusahaan setelah IPO dalam jangka waktu yang relatif panjang juga akan memberikan wawasan yang lebih luas tentang bagaimana sesungguhnya hubungan antara manajemen laba dan return saham.

\section{DAFTAR PUSTAKA}

Aharony, J., Lin, C.J., \& Leob, M.P. 1993. Initial Public Offerings, Accounting Choices, and Earnings Management. Contemporary Accounting Research, 10: 61-81. 


\section{Manajemen Laba: Bagaimana Dampaknya terhadap Ipo Underpricing?}

Andre Yulius Sahat Nauli Sitompul, Unggul Purwohedi,む Ari Warokka

Aharony, J., Lee, C.J., \& Wong, T.J. 2000. Financial Packaging of IPO firms in China. Journal of Accounting Research, 38: 103-126.

Alhadab, M., Clacher, I., \& Keasey, K. 2016. A Comparative Analysis of Real and Accrual Earnings Management Around Initial Public Offerings under Different Regulatory Environments. Journal of Business Finance \& Accounting, 43(7-8): 849-871.

Beatty, R.P. \& Ritter, J.R. 1986. Investment Banking, Reputation, and the Underpricing of Initial Public Offerings. Journal of Financial Economics, 15(1-2): 213232.

Darrough, M. \& Rangan, S. 2005. Do Insiders Manipulate Earnings When They Sell Their Shares in an Initial Public Offering? Journal of Accounting Research, 43(1): 1-33.

Dechow, P.M., Sloan, R. \& Sweeney, A. 1995. Detecting Earnings Management. The Accounting Review, 70(2): 193-225.

DuCharme, L.L., Malatesta, P.H., \& Sefcik, S.E. 2001. Earnings management: IPO Valuation and Subsequent Performance. Journal of Accounting, Auditing $\mathcal{E}$ Finance, 16(4): 369-396.

Fung, S.Y.K., Gul, F.A., \& Radhakrishnan, S. 2014. Investment Banks' Entry into New IPO Markets and IPO Underpricing. Management Science, 60(5): 12971316.

Gao, J., Cong, L.M., \& Evans, J. 2015. Earnings Management, IPO Underpricing, and Post-Issue Stock Performance of Chinese SMEs. The Chinese Economy, 48(5): 351-371.

Ghozali, I., \& Ratmono, D. 2014. Analisis Multivariat dan Ekonometrika Teori, Konsep dan Aplikasi dengan Eviews 8. Semarang: BP Undip.

Graham, J. R., Harvey, C.R., \& Rajgopal. S. 2005. The Economic Implications of Corporate Financial Reporting. Journal of Accounting and Economics, 40(1-3): 3-73.

Kao, J.L., Donghui, W., \& Yang, Z. 2009. Regulations, Earnings Management, and Post-IPO Performance: The Chinese Evidence. Journal of Banking \& Finance, 33(1): 63-76.
Karami, G., Kordlar, A.E., Amini, Y., \& Hajipour, S. 2014. Earnings Management and Underpricing of Initial Public Offerings (IPO), Evidence from Iran. International Business Research, 7(7): 156-163.

Katti, S., \& Phani, B.V. 2016. Underpricing of Initial Public Offerings: A Literature Review. Universal Journal of Accounting and Finance, 4(2):35-52.

Li, X. 2010. Real Earnings Management and Subsequent Stock Returns. Working Paper. Hong Kong University of Science and Technology.

Oktorina, M. \& Hutagaol, Y. 2008. Analisis Arus Kas Kegiatan Operasi dalam Mendeteksi Manipulasi Aktivitas Riil dan Dampaknya terhadap Kinerja Pasar. Simposium Nasional Akuntansi (SNA) XI. Pontianak.

Roosenboom, P., Goot, T., \& Mertens, G. 2003. Earnings Management and Initial Public Offerings: Evidence from the Netherlands. International Journal of Accounting, 38: 243-266.

Roychowdhury, S. 2006. Earnings Management through Real Activities Manipulation. Journal of Accounting and Economic, 42: 335-370.

Shen, Z, Coakley, J., \& Instefjord, N. 2014. Earnings Management and IPO Anomalies in China. Review of Quantitative Finance and Accounting, 42(1): 69-93.

Shen, Z., Coakley, J., \& Instefjord, N. 2009. Earnings Management, Underpricing and Underperformance of Chinese IPOs. Working Paper. Xiamen University.

Teoh, S. H., Welch, I., \& Wong, T. J. 1998a. Earnings Management and the Long run Market Performance of Initial Public Offerings. The Journal of Finance, 53(6): 1935-1974.

Teoh, S., Welch, I., \& Wong, T.J. 1998b. Earnings Management and the Subsequent Market Performance of Initial Public Offerings. Journal of Finance, 53: 19351974.

Yu, Q., Du, B., \& Sun, Q. 2006. Earnings Management at Right Issues Thresholds - Evidence from China. Journal of Banking and Finance, 30: 3453-3468. 